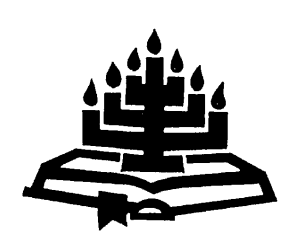

\title{
'n Beperkte empiriese ondersoek van kreatiewe prediking in die Gereformeerde Kerke in Suid-Afrika
}

\author{
B.J. de Klerk \& C.J. Nagel \\ Skool vir Kerkwetenskappe \\ Potchefstroomkampus, Noordwes-Universiteit \\ POTCHEFSTROOM \\ E-pos: kwsbjdk@puknet.puk.ac.za \\ innesnagel@lantic.net
}

\begin{abstract}
A limited empirical research project on creative preaching in the Gereformeerde Kerke in Suid-Afrika (Reformed Churches in South Africa; GKSA)
\end{abstract}

The aim of this article is to highlight the importance of creative preaching and to investigate this aspect of preaching as practised in the Gereformeerde Kerke in Suid-Afrika. For this purpose an empirical research project in the field of Practical Theology was undertaken, and certain conclusions were drawn after the responses had been analysed. Guidelines of the Likert Scale were applied as measuring instrument to gauge the level and success rate of creative preaching in the GKSA, and to indicate possible new perspectives in this regard. The outcome of this research project was, however, that only an unsatisfactory percentage of the respondents experienced the verbal expressions used by preachers as clear, plain and communicative. Respondents indicated that complicated facts of faith are not always explained satisfactorily and in a concrete way by making use of metaphors and figurative language. Consequently, these respondents experienced a lack of meaning in public worship, and inter alia ascribed it to the use of sometimes incomprehensible language that does not carry sufficient clarity of expression. In this regard a serious rift can develop between the preacher and members of the congregation as far as dialogue (interaction) in the worship service is concerned. 
Opsomming

'n Beperkte empiriese ondersoek van kreatiewe prediking in die Gereformeerde Kerke in Suid-Afrika

Die doel met hierdie artikel is om die belangrikheid van kreatiewe prediking te benadruk en na te gaan hoe hierdie aspek van prediking beoefen word deur die Gereformeerde Kerke in Suid-Afrika (GKSA). Vir hierdie doel is 'n beperkte empiriese ondersoek op die gebied van die Praktiese Teologie onderneem en sekere afleiding is gemaak nadat die response ontleed is. Die riglyne van die Likertskaal is toegepas as meetinstrument om die vlak en sukses van kreatiewe prediking in die GKSA te meet en om moontlike nuwe perspektiewe in hierdie verband aan te dui. Die afloop van hierdie ondersoekprojek was egter dat slegs 'n onbevredigende en klein persentasie van die respondente predikers se verbale uitdrukkingsvermoë as helder, eenvoudig en kommunikatief beleef. Die respondente het aangedui dat ingewikkelde geloofsfeite dikwels nie bevredigend en konkreet verduidelik word deur van metafore en beelde gebruik te maak nie. Gevolglik het hierdie respondente 'n leemte ervaar in die betekenis van openbare godsdiensbeoefening - iets wat hulle onder andere toegeskryf het aan die gebruik van dikwels onverstaanbare taal wat begrippe nie helder genoeg uitdruk nie. In hierdie opsig kan 'n ernstige breuk tussen die prediker en die gemeentelede ontwikkel sover dit die aspek van dialoog (interaksie) in die erediens aangaan.

\section{Inleiding}

Hierdie artikel sluit aan by die model wat Zerfass (1974:166 e.v.) vir die Praktiese Teologie ontwerp het. Die metode behels die volgende:

- dat basisteorieë uit die teologiese tradisie, en metateorieë uit onder andere die grenswetenskappe gevorm word en

- dat 'n ordening van resultate uit albei besinningsvelde in 'n hermeneutiese wisselwerking met die oog op praktykteoretiese perspektiewe plaasvind.

In die basisteorie (vgl. Nagel, 2002:9-53) word die belang van die werk van die Creator Spiritus) beklemtoon. Die doelwit van die ondersoek wat hierdie artikel onderlê, is onder andere die volgende:

- om, vanuit die vertrekpunte van die basisteorie (Nagel, 2002:5153), nadere inligting in te win oor kreatiewe prediking; 
- om in hierdie verband ook gebruik te maak van gegewens wat ingewin is op grond van empiriese ondersoek;

- om na te gaan op watter wyse kreatiewe prediking nuwe perspektiewe kan skep.

Venter (1996:25) toon aan dat daar binne die werklikheid van die Praktiese Teologie twee domeine van besinning aanwesig is, naamlik die kommunikatiewe handelinge in die opskrifgestelde openbaring, en die kommunikatiewe handelinge in die konkrete bediening daarvan in die kerk. Voordat praktykteoreties besin kan word, moet die tema kreatiewe prediking wat 'n nuwe perspektief skep, aan die hand van empiriese gegewens ontleed word (vgl. Venter, 1996:25). Die doel van empiriese ondersoek is altyd om kennis te genereer wat dit moontlik sal maak om 'n huidige, onbevredigende situasie na meer aanvaarbaar te verander (Heitink, 1999:223-225). Heitink (1999:221) toon dat die woord empiries afgelei is van die Griekse woord emperia - wat ervaring beteken. Met empiriese navorsing word deur die ervaring bepaal hoe die basisteorie in die praktykteorie funksioneer. Hierdie empiriese perspektief koppel die basisteorie aan die praktykteorie. Praktiese Teologie het veral te make met kommunikatiewe handelinge in diens van die evangelie in die huidige tyd en dit kan alleen met empiriese metodologie ondersoek word (Heyns \& Pieterse, 1990:73).

Daar bestaan volgens Heitink (1999:229-231) verskeie metodes van empiriese navorsing: beskrywend, verkennend en die toets van hipoteses.

- Beskrywende navorsing fokus op 'n sistematiese beskrywing van 'n tema op grond van empiriese data (Heitink, 1999:229).

- Die klem van verkennende navorsing lê op die verduideliking en interpretasie van gegewens waaroor min bekend is en geen teorie nog daaroor ontwikkel is nie (Heitink, 1999:230).

- In navorsing waarin die geldigheid van bepaalde hipoteses getoets word, word bepaal of daar bande tussen die werklikheid en die teoretiese grond bestaan (Heitink, 1999:231).

In hierdie artikel word verkennend navorsing gedoen om te bepaal wat die huidige stand van kreatiewe prediking in vier gemeentes van die GKSA is. 


\section{2. 'n Empiriese ondersoek van kreatiewe prediking wat 'n nuwe perspektief kan skep}

\subsection{Die noodsaak van die empiriese ondersoek}

Die doel van die navorsing wat hierdie artikel onderlê, is om by wyse van 'n meningskaal 'n nadere ondersoek te doen van die gesindheid van hoorders teenoor prediking. Verder word nagegaan of kreatiewe prediking daartoe kan bydra om negatiewe gesindhede te verander en nuwe perspektiewe te skep. In die Praktiese Teologie toon resente navorsing 'n gerigtheid op die noodsaak van prediking wat nuwe perspektiewe skep, maar sonder dat verduidelik word hoe dit moet gebeur: In 'n aantal artikels wat in Praktiese Teologie (15(1)) gepubliseer is, vestig dié skrywers byvoorbeeld die aandag op die uiteenlopende aard van gesindhede wat die Suid-Afrikaanse jeug openbaar. Die uiteenlopende aard van die gesindhede stel volgens die outeurs eise aan die praktiese bediening van die kerk, dus ook aan kreatiewe prediking. Vos (1999:126) toon aan dat prediking wat aan die adres van hoorders gerig word, hoorders op hulle lewensweg moet begelei en daarom kreatief moet wees. Kruger (1999:106) verduidelik dat die prediker instrumenteel is in die prediking. Die prediker moet lidmate in gesprek met God bring. Nel (2000:112) toon in sy navorsing aan dat persoonlike prediking (wat kreatiwiteit van die prediker verg) hoorders aanraak en in beweging bring.

Die teologiese uitgangspunte waarop die empiriese navorsing vir hierdie artikel berus, en dus ook die stellings in die vraelys, bou op die baanbrekerswerk wat op Reformatoriese gebied gedoen is deur H.J.C. Pieterse, G.D.J. Dingemans en C.J.A. Vos. Hierdie outeurs het nuwe insigte oor kreatiewe prediking daargestel (hermeneutiese, kommunikatiewe, taalhandelingsteoretiese, dialogiese aspekte, en die wyse waarop die prediking gekonkretiseer behoort te word). Belangwekkende werke op hierdie gebiede is veral dié van Pieterse (1979, 1986, 1988, 1990, 1991, 1992 en 2001), Vos (1996) en Dingemans (1991).

\subsection{Metode}

Vir die empiriese navorsing wat hierdie artikel aanvul, is gebruik gemaak van die Likertskaal. Vir so 'n skaal stel die navorser 'n lys items saam wat na sy mening gunstig of ongunstig verband hou met die gesindhede wat ondersoek word (Cilliers, 1983:103). Die items word as stellings geformuleer ten opsigte waarvan respondente kan aandui of hulle daarmee sterk verskil, matig verskil, neutraal staan, 
gedeeltelik saamstem of volkome saamstem (Dane, 1990:264). Numeriese waardes van 1-5 word aan die verskillende moontlike antwoorde by elke item toegeken. Die reaksie wat die meer gunstige gesindheid reflekteer, ontvang die laagste numeriese waarde. Die totale telling van elke respondent bestaan uit die som van die tellings ten opsigte van al die items tesame (Cilliers, 1983:103). Elke item word ontleed om vas te stel watter items die duidelikste onderskei tussen persone wat 'n hoë telling behaal en dié wat oor die geheel 'n lae telling behaal (vgl. die volledige uiteensetting van Kruger, 2002:164 e.v.).

Die vraelyste is met kontakpersone in vier gemeentes bespreek waarna 'n uitnodiging aan hoorders gerig is om deel te neem aan die invul van die vraelys. Die navorsing is dus by wyse van beskikbaarheidseleksie gedoen, aangesien hoorders 'n keuse kon uitoefen in die invul van die vraelys. In die keuse van die vier gemeentes is gepoog om 'n gebalanseerde verspreiding van plattelandse en stedelike gemeentes te betrek. In die uitdeel van die vraelyste is verder gelet op die verspreiding van die vraelyste aan hoorders tussen die ouderdom van 11 tot 80 jaar. In die navorsing het die klem geval op homileties-empiriese navorsing waarin die bevindings vanuit die basisteoretiese asook metateoretiese bevindings getoets is aan die hand van die Likertskaal (Nagel, 2002:51-53; 72-73).

Die keuse van slegs vier gemeentes binne die GKSA mag moontlik neig na eensydigheid in die navorsing. Tog was die doel van die ondersoek nie om in die eerste plek 'n omvattende empiriese studie te doen nie, maar wel om vanuit die homileties-empiriese navorsing enkele beskouings en tendense wat moontlik onder predikers en hoorders voorkom, van naderby te beskou.

\subsection{Respondente}

Die respondente het bestaan uit lidmate van die Gereformeerde Kerke in Suid-Afrika en was tussen die ouderdom van 11 en 80 jaar.

\subsection{Meetinstrumente}

Cilliers (1983:101-103) asook Smit (1985:146-147) toon in hulle navorsing die vereistes waaraan meetinstrumente moet voldoen. Cilliers (1983:102) bespreek rangordeskale as geldige meetinstrument. In teenstelling met die oordeelskale waar van beoordelaars gebruik gemaak word, word rangordeskale opgestel deur middel van itemseleksie. Die numeriese waardes wat aan die items toegeken word, word met die statiese verwerking hiervan 
bewerkstellig. Die Likertskaal is volgens Cilliers (1983:103) 'n voorbeeld van die tegniek van skaalkonstruksie.

Smit (1985:147) verwys in sy navorsing na die vereistes vir geldigheid wat gestel word. Die outeur toon aan dat die data wat ingesamel word, informasie moet verskaf oor die veld van ondersoek. Smit (1985:147 - soos aangehaal deur Kruger (2002:168)) verwys in die navorsing na die volgende aspekte:

- Inhoudsgeldigheid, dit wil sê die mate waarin ingesamelde data die gedragsaspek wat ondersoek word, verteenwoordig.

- Voorspellingsgeldigheid wat betrekking het op die mate waarop daar op grond van die ingesamelde gegewens voorspellings gemaak kan word.

- Samevallende geldigheid wat na die verband tussen die data en 'n bepaalde kriterium verwys.

- Teoretiese geldigheid wat betrekking het op die geldigheid van die teoretiese konstruksie.

In die opstel van die vraelys is items (stellings) geformuleer wat te make het met prediking, prediker, hoorders en kreatiwiteit.

\subsection{Die Likertskaal (vgl. Kruger, 2002:169)}

Die vraelys is anoniem ingevul

Tipe gemeente

Geslag

Ouderdom

\begin{tabular}{|l|l|l|l|}
\hline Platteland & & Stedelik & \\
\hline \multicolumn{4}{|l|}{} \\
\hline Manlik & & Vroulik & \\
\hline
\end{tabular}

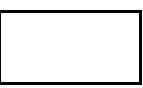

\subsubsection{Tipe vrae wat geformuleer is}

Maak 'n kruisie in die blokkie wat u mening die beste weergee.

Die taal wat die prediker gebruik, is duidelik, keurig en eenvoudig genoeg sodat kinders dit kan verstaan.

\begin{tabular}{|l|l|l|l|l|}
\hline Verskil sterk & Verskil sterk & Neutraal & $\begin{array}{l}\text { Stem } \\
\text { gedeeltelik } \\
\text { saam }\end{array}$ & $\begin{array}{l}\text { Stem } \\
\text { volkome } \\
\text { saam }\end{array}$ \\
\hline 1 & 2 & 3 & 4 & 5 \\
\hline
\end{tabular}


Die predikant maak dikwels gebruik van treffende beelde (metafore) om ingewikkelde geloofsfeite te verduidelik.

\begin{tabular}{|l|l|l|l|l|}
\hline Verskil sterk & Verskil sterk & Neutraal & $\begin{array}{l}\text { Stem } \\
\text { gedeeltelik } \\
\text { saam }\end{array}$ & $\begin{array}{l}\text { Stem } \\
\text { volkome } \\
\text { saam }\end{array}$ \\
\hline 1 & 2 & 3 & 4 & 5 \\
\hline
\end{tabular}

Lank na 'n Sondag onthou ek steeds die tema, hoofpunte en sentrale boodskap van die preek.

\begin{tabular}{|l|l|l|l|l|}
\hline Verskil sterk & Verskil sterk & Neutraal & $\begin{array}{l}\text { Stem } \\
\text { gedeeltelik } \\
\text { saam }\end{array}$ & $\begin{array}{l}\text { Stem } \\
\text { volkome } \\
\text { saam }\end{array}$ \\
\hline 1 & 2 & 3 & 4 & 5 \\
\hline
\end{tabular}

Omdat preke oninteressant en langdradig is, sukkel ek om te konsentreer.

\begin{tabular}{|l|l|l|l|l|}
\hline Verskil sterk & Verskil sterk & Neutraal & $\begin{array}{l}\text { Stem } \\
\text { gedeeltelik } \\
\text { saam }\end{array}$ & $\begin{array}{l}\text { Stem } \\
\text { volkome } \\
\text { saam }\end{array}$ \\
\hline 1 & 2 & 3 & 4 & 5 \\
\hline
\end{tabular}

Indien ek preke nie verstaan nie en/of dit nie verrykend vind nie, is dit nie die moeite werd om eredienste by te woon nie.

\begin{tabular}{|l|l|l|l|l|}
\hline Verskil sterk & Verskil sterk & Neutraal & $\begin{array}{l}\text { Stem } \\
\text { gedeeltelik } \\
\text { saam }\end{array}$ & $\begin{array}{l}\text { Stem } \\
\text { volkome } \\
\text { saam }\end{array}$ \\
\hline 1 & 2 & 3 & 4 & 5 \\
\hline
\end{tabular}

Ek het 'n behoefte om met die predikant en/of medegelowiges oor die preke te gesels.

\begin{tabular}{|l|l|l|l|l|}
\hline Verskil sterk & Verskil sterk & Neutraal & $\begin{array}{l}\text { Stem } \\
\text { gedeeltelik } \\
\text { saam }\end{array}$ & $\begin{array}{l}\text { Stem } \\
\text { volkome } \\
\text { saam }\end{array}$ \\
\hline 1 & 2 & 3 & 4 & 5 \\
\hline
\end{tabular}


Tydens die erediens, en dan veral tydens die prediking, beleef en ervaar ek dat God self aan die Woord is.

\begin{tabular}{|l|l|l|l|l|}
\hline Verskil sterk & Verskil sterk & Neutraal & $\begin{array}{l}\text { Stem } \\
\text { gedeeltelik } \\
\text { saam }\end{array}$ & $\begin{array}{l}\text { Stem } \\
\text { volkome } \\
\text { saam }\end{array}$ \\
\hline 1 & 2 & 3 & 4 & 5 \\
\hline
\end{tabular}

'n Goeie preek is 'n preek wat verduidelik wat die teks sê en hoe ek dit prakties in my lewe moet toepas.

\begin{tabular}{|l|l|l|l|l|}
\hline Verskil sterk & Verskil sterk & Neutraal & $\begin{array}{l}\text { Stem } \\
\text { gedeeltelik } \\
\text { saam }\end{array}$ & $\begin{array}{l}\text { Stem } \\
\text { volkome } \\
\text { saam }\end{array}$ \\
\hline 1 & 2 & 3 & 4 & 5 \\
\hline
\end{tabular}

Die prediking inspireer my om iets in my lewe te verander.

\begin{tabular}{|l|l|l|l|l|}
\hline Verskil sterk & Verskil sterk & Neutraal & $\begin{array}{l}\text { Stem } \\
\text { gedeeltelik } \\
\text { saam }\end{array}$ & $\begin{array}{l}\text { Stem } \\
\text { volkome } \\
\text { saam }\end{array}$ \\
\hline 1 & 2 & 3 & 4 & 5 \\
\hline
\end{tabular}

Die prediking inspireer my om aktief iets te gaan doen.

\begin{tabular}{|l|l|l|l|l|}
\hline Verskil sterk & Verskil sterk & Neutraal & $\begin{array}{l}\text { Stem } \\
\text { gedeeltelik } \\
\text { saam }\end{array}$ & $\begin{array}{l}\text { Stem } \\
\text { volkome } \\
\text { saam }\end{array}$ \\
\hline 1 & 2 & 3 & 4 & 5 \\
\hline
\end{tabular}

2.6 Ontleding van die verskillende soorte gesindhede soos vervat in 'n gesindheidskaal

\subsubsection{Wyse van rapportering}

In die ontleding sal die verskillende response wat ontvang is, aan die hand van frekwensietabelle aangetoon word. In dié onderafdeling sal die biografiese gegewens van respondente aangedui word. Die ontleding van die response sal daarna onder 'n aparte afdeling eers aangetoon word, waarna sekere afleidings gemaak sal word. 


\subsubsection{Ontleding van verskillende soorte gesindhede}

\subsubsection{Biografiese gegewens}

Honderd en dertien (94,17\%) uit 'n moontlike een honderd en twintig respondente het gereageer op die uitnodiging om die vraelys in te vul. Die respondente is verteenwoordigend van stedelike sowel as plattelandse gemeentes. Uit die stedelike gemeentes het 53 respondente gereageer, terwyl 60 respondente uit plattelandse gemeentes gereageer het. Die studiepopulasie word onderskeidelik geïdentifiseer as $A 1, A 2, B 1$ en $B 2$. $A 1$ is verteenwoordigend van 'n groot stedelike gemeente, terwyl A2 verwys na 'n kleiner stedelike gemeente. B1 en B2 verwys onderskeidelik na 'n groot en kleiner plattelandse gemeente. In die frekwensietabel hier onder word die biografiese profiel van die respondente vervolgens uiteengesit:

\begin{tabular}{|c|c|c|c|c|}
\hline Area & Frekwensie & Persentasie & $\begin{array}{c}\text { Kumulatiewe } \\
\text { frekwensie }\end{array}$ & $\begin{array}{c}\text { Kumulatiewe } \\
\text { persentasie }\end{array}$ \\
\hline A1 & 23 & 20,35 & 23 & 20,35 \\
\hline A2 & 30 & 26,55 & 53 & 46,90 \\
\hline B1 & 30 & 26,55 & 83 & 73,45 \\
\hline B2 & 30 & 26,55 & 113 & 100,00 \\
\hline
\end{tabular}

Drie en vyftig manlike (46,90\%) respondente en 60 (53,10\%) vroulike respondente het gereageer op die uitnodiging om deel te neem aan die invul van die vraelyste.

\begin{tabular}{|c|c|c|c|c|}
\hline Geslag & Frekwensie & Persentasie & $\begin{array}{c}\text { Kumulatiewe } \\
\text { frekwensie }\end{array}$ & $\begin{array}{c}\text { Kumulatiewe } \\
\text { persentasie }\end{array}$ \\
\hline $\mathrm{Ml}$ & 53 & 46,90 & 53 & 46,60 \\
\hline $\mathrm{Vr}$ & 60 & 53,10 & 113 & 100,00 \\
\hline
\end{tabular}

Wat ouderdomsverspreiding betref, is vraelyste uitgedeel aan lidmate tussen die ouderdomme van 11 en 80 . Die verspreiding van respondente word in vier onderskeie groepe ingedeel, naamlik, onder 25 jaar, 25-39 jaar, 40-59 jaar, 60 plus jaar. 


\begin{tabular}{|c|c|c|c|c|}
\hline Ouderdom & Frekwensie & Persentasie & $\begin{array}{c}\text { Kumulatiewe } \\
\text { frekwensie }\end{array}$ & $\begin{array}{c}\text { Kumulatiewe } \\
\text { persentasie }\end{array}$ \\
\hline Onder 25 jr & 28 & 24,78 & 113 & 100,00 \\
\hline $25-39 \mathrm{jr}$ & 26 & 23,01 & 26 & 23,01 \\
\hline $40-59 \mathrm{jr}$ & 34 & 30,09 & 60 & 53,10 \\
\hline $60+\mathrm{jr}$ & 25 & 22,12 & 85 & 75,22 \\
\hline
\end{tabular}

\subsubsection{Ontleding van response op die verskillende stellings}

\subsubsection{Hoorders se ervaring van die prediker se taalgebruik}

Met stelling 1: Die taal wat die prediker gebruik, is duidelik, keurig en eenvoudig genoeg sodat kinders dit kan verstaan, het respondente soos volg gereageer:

\begin{tabular}{|c|c|c|c|c|}
\hline Stelling & Frekwensie & Persentasie & $\begin{array}{c}\text { Kumulatiewe } \\
\text { frekwensie }\end{array}$ & $\begin{array}{c}\text { Kumulatiewe } \\
\text { persentasie }\end{array}$ \\
\hline 1 & 1 & 0,88 & 1 & 0,88 \\
\hline 2 & 4 & 3,54 & 5 & 4,42 \\
\hline 4 & 86 & 76,11 & 27 & 23,89 \\
\hline 5 & 22 & 19,47 & 113 & 100,00 \\
\hline
\end{tabular}

Die respons beklemtoon dat die oorgrote meerderheid van die respondente $(95,58 \%)$, gedeeltelik of volkome saamstem met die stelling dat die taal wat die prediker gebruik, duidelik, keurig en eenvoudig is. Slegs $4,42 \%$ van die respondente verskil sterk of matig met hierdie stelling. Alhoewel dit mag voorkom asof hierdie situasie bevredigend is, is dit tog kommerwekkend dat slegs $19,47 \%$ van die respondente volkome oortuig is van die feit dat die prediker se taalgebruik duidelik, keurig en eenvoudig is. Om hierdie persentasie te verbeter sal predikers egter ernstig moet besin oor die effektiwiteit van hul taalgebruik in die prediking.

\subsubsection{Hoorders se ervaring van die prediker se kreatiewe aanwending van treffende beelde en metafore}

Respondente het soos volg gereageer op stelling 2: Die predikant maak dikwels gebruik van treffende beelde om ingewikkelde geloofsfeite te verduidelik: 
B.J. de Klerk \& C.J. Nagel

\begin{tabular}{|c|c|c|c|c|}
\hline Stelling & Frekwensie & Persentasie & $\begin{array}{c}\text { Kumulatiewe } \\
\text { frekwensie }\end{array}$ & $\begin{array}{c}\text { Kumulatiewe } \\
\text { persentasie }\end{array}$ \\
\hline 2 & 4 & 3,54 & 4 & 3,54 \\
\hline 3 & 11 & 9,73 & 15 & 13,27 \\
\hline 4 & 24 & 21,24 & 39 & 34,51 \\
\hline 5 & 74 & 65,49 & 113 & 100,00 \\
\hline
\end{tabular}

Die meerderheid van die respondente $(86,73 \%)$ het te kenne gegee dat hulle óf gedeeltelik óf volkome daarmee saamstem dat die prediker dikwels gebruik maak van metaforiese taalgebruik om ingewikkelde geloofsfeite te verduidelik. 'n Beduidende aantal respondente $(65,49 \%)$ het volkome met die stelling saamgestel, terwyl $21,24 \%$ van die respondente gedeeltelik saamgestem het. Dit is opvallend dat $9,73 \%$ van die respondente 'n neutrale gesindheid in dié opsig openbaar. Slegs 3,54\% van die respondente het matig van die stelling verskil. Uit bogenoemde ondersoek kan basies twee afleidings gemaak word. In die eerste plek word dit duidelik dat predikers, deur gebruik te maak van treffende beelde en metaforiese taalgebruik, suksesvol daarin slaag om ingewikkelde geloofsfeite aan hoorders te verduidelik. Tweedens, meer krities geëvalueer, is daar 'n persentasie respondente $(34,51 \%)$ wat nie ten volle oortuig is dat predikers ingewikkelde geloofsfeite verduidelik aan die hand van beeldryke en metaforiese taal nie. Hierdie gebrek aan beeldryke taal kan tot gevolg hê dat hoorders teleurgestel is met die prediking, omdat ingewikkelde geloofsfeite steeds nie helder en deur middel van konkrete beelde verduidelik word nie.

\subsubsection{Die prediker se vermoë om die boodskap effektief en kreatief oor te dra}

Respondente het soos volg gereageer op stelling 3: Dit is wel die geval dat ek lank na Sondag steeds die tema, hoofpunte en sentrale boodskap van die preek kan onthou:

\begin{tabular}{|c|c|c|c|c|}
\hline Stelling & Frekwensie & Persentasie & $\begin{array}{c}\text { Kumulatiewe } \\
\text { frekwensie }\end{array}$ & $\begin{array}{c}\text { Kumulatiewe } \\
\text { persentasie }\end{array}$ \\
\hline 1 & 1 & 0,88 & 1 & 0,88 \\
\hline 2 & 7 & 6,19 & 8 & 7,08 \\
\hline 3 & 15 & 13,28 & 23 & 20,35 \\
\hline 4 & 62 & 54,86 & 75 & 66,37 \\
\hline 5 & 28 & 24,78 & 113 & 100,00 \\
\hline
\end{tabular}


Die meerderheid van die respondente $(79,63 \%)$ het aangedui dat hulle óf gedeeltelik $(54,86 \%)$ óf volkome $(24,77 \%)$ saamstem dat hulle lank na Sondag steeds die tema, hoofpunte en sentrale boodskap van die preek kan onthou. 'n Kleinerige persentasie $(7,07 \%)$ van die respondente het aangedui dat hulle matig of sterk verskil van die stelling, terwyl $13,28 \%$ neutraal teenoor die stelling gestaan het. Dit is nie heeltemal duidelik waarom respondente in die geval van bogenoemde stelling neutraal staan nie. Slegs 'n klein persentasie van die respondente $(24,78 \%)$ het egter aangetoon dat hulle volkome saamstem dat hulle die tema en sentrale boodskap van die preek kan onthou. Die res van die respondente $(75,22 \%)$ is egter nie so seker nie. Die afleiding kan daarom gemaak word dat hoorders probleme ervaar as dit kom by die onthou van wat Sondag gepreek is. Wat die situasie verder problematies maak, is die feit dat slegs 'n skrale $20 \%$ van dit wat gesê word, deur hoorders onthou word (vgl. Schütz, 1981:44). Predikers word dus gekonfronteer met die feit dat hul prediking meer effektief en kreatief met die hoorder van vandag sal moet kommunikeer.

\subsubsection{Die prediker se vermoë om belangstelling te prikkel en gedagtes te boei}

Respondente het soos volg gereageer op stelling 4: Omdat preke oninteressant en langdradig is, sukkel ek om te konsentreer.

\begin{tabular}{|c|c|c|c|c|}
\hline Stelling & Frekwensie & Persentasie & $\begin{array}{c}\text { Kumulatiewe } \\
\text { frekwensie }\end{array}$ & $\begin{array}{c}\text { Kumulatiewe } \\
\text { persentasie }\end{array}$ \\
\hline 1 & 78 & 69,03 & 78 & 69,03 \\
\hline 2 & 13 & 11,50 & 91 & 80,53 \\
\hline 3 & 8 & 7,08 & 99 & 87,61 \\
\hline 4 & 10 & 8,85 & 109 & 96,46 \\
\hline 5 & 4 & 3,54 & 113 & 100,00 \\
\hline
\end{tabular}

Die meerderheid van die respondente $(80,53 \%)$ het aangedui dat hulle gedeeltelik of volkome met die stelling verskil. Op grond hiervan word 'n positiewe gesindheid aangedui teenoor prediking wat bestempel kan word as interessant en boeiend. Uit die gesindheidskaal blyk dit dat 14 respondente, (d.w.s. 12,39\%) meen dat hulle die prediking as oninteressant en langdradig ervaar. Laasgenoemde faktore dra gevolglik daartoe by dat die konsentrasievermoë van die hoorder negatief geraak word. Op grond van die response blyk dit dat $8,85 \%$ van die respondente 
neutraal teenoor die stelling staan. Aangesien dit 'n gesindheidskaal is waarmee gewerk word, is dit nie duidelik waarom die respondente 'n neutrale gesindheid in dié verband het nie. Vanuit bogenoemde ondersoek kan die afleiding gemaak word dat die wyse waarop die prediker die boodskap oordra, 'n prominente rol speel in die hoorders se vermoë om te konsentreer.

\subsubsection{Gesindheid van hoorders ten opsigte van erediens- bywoning}

Respondente het soos volg gereageer op stelling 5: Indien ek preke nie verstaan nie en/of dit nie verrykend vind nie, is dit nie die moeite werd om eredienste by te woon nie.

\begin{tabular}{|c|c|c|c|c|}
\hline Stelling & Frekwensie & Persentasie & $\begin{array}{c}\text { Kumulatiewe } \\
\text { frekwensie }\end{array}$ & $\begin{array}{c}\text { Kumulatiewe } \\
\text { persentasie }\end{array}$ \\
\hline 1 & 81 & 71,68 & 81 & 71,68 \\
\hline 2 & 10 & 8,85 & 91 & 80,53 \\
\hline 3 & 8 & 7,08 & 99 & 87,61 \\
\hline 4 & 4 & 3,54 & 103 & 91,15 \\
\hline 5 & 10 & 8,85 & 113 & 100,00 \\
\hline
\end{tabular}

Die meerderheid van die respondente $(81,53 \%)$ verskil sterk of matig van die stelling. Uit die respons blyk dit dat respondente positief ingestel is teenoor die noodsaaklikheid om eredienste by te woon - ten spyte van die moontlikheid dat preke onverstaanbaar mag wees. Die response toon ook hul kommer - 19,47\% van die respondente het naamlik te kenne gegee dat hulle óf neutraal staan, óf gedeeltelik/volkome saamstem dat onverstaanbare preke die sinvolheid van eredienste beïnvloed. Alhoewel die meerderheid van die respondente positief reageer op eredienste, is dit tog kommerwekkend dat hoorders onverstaanbare prediking as 'n rede aantoon waarom die sinvolheid van erediensbywoning in gedrang kom. Predikers het daarom die baie belangrike taak om moeite te doen met hul prediking, sodat die boodskap eenvoudig en verstaanbaar aan hoorders gekommunikeer en as verrykend ervaar sal word.

\subsubsection{Die behoefte aan kommunikasie, voor en na die erediens}

Die respondente het soos volg gereageer op stelling 6: Ek het die behoefte om met die predikant en/of medegelowiges oor die preke te gesels: 
'n Beperkte empiriese ondersoek van kreatiewe prediking in die GKSA

\begin{tabular}{|c|c|c|c|c|}
\hline Stelling & Frekwensie & Persentasie & $\begin{array}{c}\text { Kumulatiewe } \\
\text { frekwensie }\end{array}$ & $\begin{array}{c}\text { Kumulatiewe } \\
\text { persentasie }\end{array}$ \\
\hline 1 & 1 & 0,88 & 1 & 0,88 \\
\hline 2 & 4 & 3,54 & 5 & 4,42 \\
\hline 3 & 20 & 17,70 & 25 & 22,12 \\
\hline 4 & 42 & 37,17 & 67 & 59,29 \\
\hline 5 & 46 & 40,71 & 113 & 100,00 \\
\hline
\end{tabular}

By stelling 6 het $(40,71 \%)$ van die respondente aangetoon dat hulle volkome saamstem dat hulle die behoefte het om met hulle predikant of medegelowiges oor die preke te gesels. 'n Verdere $37,17 \%$ het aangetoon dat hulle gedeeltelik saamstem met die stelling. Slegs $4,42 \%$ van die respondente het aangetoon dat hulle nie die behoefte vir só 'n gesprek het nie. Die afleiding kan gemaak word dat daar 'n groot behoefte onder lidmate bestaan om in gesprek te tree met die predikant of ander medegelowiges oor die preke. Hierdie behoefte is ' $n$ bevestiging van die feit dat die postmoderne mens nie 'n toeskouer wil wees nie, maar aktief wil deelneem en sodoende ook alles vir homself deursigtig maak (vgl. De Klerk, 1999:24).

Die preekgesprek voor en na die prediking kan predikers help om nie in eensaamheid hul preekvoorbereiding te doen nie. Sodoende word die gemeente ook meegeneem in die proses van preekvoorbereiding en preeklewering. Hoorders kry langs die weg van gesprek met die predikant en medegelowiges die geleentheid om 'n dieptegesprek oor preke te voer. Ook wat kommunikasie tussen prediker en hoorder betref, kan in hierdie opsig dus ook sprake wees van 'n dinamiese proses van interaksie en terugvoer, wat onontbeerlik vir die prediking is.

\subsubsection{Hoorders se ervaring dat God self aan die woord is}

Respondente het soos volg gereageer op stelling 7: Tydens die erediens en dan veral tydens die prediking beleef en ervaar ek dat God self aan die woord is:

\begin{tabular}{|c|c|c|c|c|}
\hline Stelling & Frekwensie & Persentasie & $\begin{array}{c}\text { Kumulatiewe } \\
\text { frekwensie }\end{array}$ & $\begin{array}{c}\text { Kumulatiewe } \\
\text { persentasie }\end{array}$ \\
\hline 1 & 2 & 1,77 & 2 & 1,77 \\
\hline 3 & 5 & 4,42 & 7 & 6,16 \\
\hline 4 & 23 & 20,35 & 30 & 26,55 \\
\hline 5 & 83 & 73,45 & 113 & 100,00 \\
\hline
\end{tabular}


Die meerderheid van die respondente $(93,80 \%)$ het aangetoon dat hulle tydens die erediens en dan veral tydens die prediking ervaar dat God self aan die woord is. Slegs 1,77\% van die respondente het laat blyk dat hulle volkome met die stelling verskil. Dit is verder opvallend om daarop te let dat $4,42 \%$ van die respondente neutraal teenoor hierdie stelling staan. Aangesien dit ' $n$ gesindheidskaal is waarmee gewerk word, is dit nie duidelik waarom die respondente 'n neutrale gesindheid in hierdie verband het nie. Prediking is alleen prediking as God self aan die woord kom en daarom is dit onontbeerlik dat predikers dit altyd in gedagte sal hou en nie die preekstoel so "vol" sal staan dat daar weinig of selfs geen plek vir God is nie. Wanneer die prediker begin preek "so sê die dominee" en nie meer "so spreek die Here, HERE" nie, dan is dit nie meer prediking nie, maar 'n moralistiese lesing.

\subsubsection{8 'n Goeie preek verduidelik wat die teks sê en verduidelik hoe dit in die praktyk uitgeleef en toegepas moet word}

Respondente het soos volg gereageer op stelling 8: 'n Goeie preek is 'n preek wat verduidelik wat die teks sê en hoe ek dit prakties in my lewe moet toepas:

\begin{tabular}{|c|c|c|c|c|}
\hline Stelling & Frekwensie & Persentasie & $\begin{array}{c}\text { Kumulatiewe } \\
\text { frekwensie }\end{array}$ & $\begin{array}{c}\text { Kumulatiewe } \\
\text { persentasie }\end{array}$ \\
\hline 2 & 1 & 0,88 & 1 & 0,88 \\
\hline 3 & 1 & 0,88 & 2 & 1,77 \\
\hline 4 & 11 & 9,73 & 13 & 11,50 \\
\hline 5 & 100 & 88,50 & 113 & 100,00 \\
\hline
\end{tabular}

Die meerderheid van die respondente $(93,80 \%)$ het duidelik laat blyk dat 'n goeie preek verduidelik wat die teks sê en verduidelik hoe dit in die praktyk van die lewe toegepas moet word. Dit is dus baie belangrik dat 'n prediker in sy preekvoorbereiding getrou aan die teks met sy hoorders moet omgaan. Alhoewel 'n klein persentasie $(12,39 \%)$ respondente in stelling 4 aangetoon het dat hulle sukkel om te konsentreer omdat die prediking vervelig en langdradig is, openbaar hulle wel 'n gunstige gesindheid teenoor prediking wat verduidelik wat die teks sê, en 'n toepassing op hul eie lewens bied.

\subsubsection{Kreatiewe prediking wat nuwe perspektief skep}

Respondente het soos volg gereageer op stelling 9: Die prediking inspireer my om iets in my lewe te verander: 


\begin{tabular}{|c|c|c|c|c|}
\hline Stelling & Frekwensie & Persentasie & $\begin{array}{c}\text { Kumulatiewe } \\
\text { frekwensie }\end{array}$ & $\begin{array}{c}\text { Kumulatiewe } \\
\text { persentasie }\end{array}$ \\
\hline 1 & 2 & 1,77 & 2 & 1,77 \\
\hline 2 & 1 & 0,88 & 3 & 2,65 \\
\hline 3 & 2 & 1,77 & 5 & 4,42 \\
\hline 4 & 24 & 21,24 & 29 & 25,66 \\
\hline 5 & 84 & 74,34 & 113 & 100,00 \\
\hline
\end{tabular}

Die meerderheid respondente $(95,55 \%)$ het aangedui dat hulle volkome $(74,34 \%)$ of gedeeltelik $(21,24 \%)$ saamstem met die stelling dat die prediking hulle inspireer om iets in hulle lewe te verander. Slegs 1,65\% van die respondente het volkome of matig met die stelling verskil. Verder het $1,77 \%$ van die respondente aangetoon dat hulle neutraal staan teenoor die stelling. Vanuit bogenoemde bevindings kan die afleiding gemaak word dat prediking ' $n$ groot rol kan speel in die verandering van verkeerde gesindhede en lewenswyses.

Respondente het soos volg gereageer op stelling 10: Die prediking inspireer my om aktief iets te gaan doen:

\begin{tabular}{|c|c|c|c|c|}
\hline Stelling & Frekwensie & Persentasie & $\begin{array}{c}\text { Kumulatiewe } \\
\text { frekwensie }\end{array}$ & $\begin{array}{c}\text { Kumulatiewe } \\
\text { persentasie }\end{array}$ \\
\hline 1 & 2 & 1,77 & 2 & 1,77 \\
\hline 2 & 2 & 1,77 & 4 & 3,54 \\
\hline 3 & 9 & 7,96 & 13 & 11,50 \\
\hline 4 & 29 & 25,66 & 42 & 37,17 \\
\hline 5 & 71 & 62,83 & 113 & 100,00 \\
\hline
\end{tabular}

'n Groot aantal respondente (62,83\%) het aangedui dat preke hulle inspireer om aktief iets te gaan doen. 'n Kleiner persentasie respondente $(25,66 \%)$ het aangedui dat hulle gedeeltelik saamstem met die stelling, terwyl $2,54 \%$ van die respondente gedeeltelik of volkome met die stelling verskil het. Verder het dit duidelik geword dat 7,96\% respondente 'n neutrale gesindheid teenoor die stelling openbaar. Hoorders toon 'n positiewe gesindheid teenoor die prediking, wat aandui dat hulle hulle laat lei deur wat die Woord openbaar. Dit is daarom noodsaaklik dat die prediking primêr 
Woordverkondiging sal wees wat erns maak met die verklaring en toepassing van die Heilige Skrif.

Met inagneming van stelling 10 wat met hierdie stelling korreleer, kan die volgende interessante afleiding gemaak word: die respons op stelling 9 dui aan dat 95,55\% van die respondente meen dat die prediking hulle aanspoor om iets in hul lewe te verander, terwyl die respons op stelling 10 'n heelwat kleiner persentasie $(88,49 \%)$ lidmate aandui wat voel dat die prediking hulle inspireer om aktief iets te gaan doen. Prediking behoort nie net tot die hoorder se verstand te spreek nie, maar moet hom ook in beweging bring sodat hy opgewonde gelaat en gevolglik daartoe aangespoor kan word om te verander en daadwerklik en aktief iets te gaan doen. Dit is hier waar kreatiwiteit, in veral die verklaring en toepassing van die Skrif, 'n belangrike rol kan speel by die daarstelling van nuwe perspektief.

\subsubsection{Gevolgtrekkings}

- Die teologiese onderbou van prediking, vanuit 'n Reformatoriese gesigspunt, is van wesentlike belang. Hierin is die werk van die Heilige Gees deurslaggewend. Die hermeneutiese, kommunikatiewe, taalhandelingsteoretiese, dialogiese aspekte en die konkretisering van die inhoud van die prediking is egter ook belangrik (vgl. punt 2.1)

- Die belangrike funksie van duidelike, keurige en eenvoudige taalgebruik in die prediking kan nie genoeg beklemtoon word nie.

- Kreatiewe predikers slaag suksesvol daarin om ingewikkelde geloofsfeite aan hoorders te verduidelik deur gebruik te maak van treffende beelde en metaforiese taalgebruik.

- Hoorders ervaar probleme as dit kom by die onthou van wat Sondag gepreek is - 'n skrale $24,78 \%$ van die respondente was volkome oortuig dat hulle lank na die erediens steeds die sentrale boodskap en tema kon onthou. Predikers word daarom gekonfronteer met die feit dat hul prediking meer effektief en kreatief met die hoorder van vandag sal moet kommunikeer.

- Die kreatiewe wyse waarop die prediker die boodskap oordra, speel 'n prominente rol in die hoorders se vermoë om aandagtig te konsentreer op dit wat gepreek word.

- Alhoewel die meerderheid van die respondente positief reageer op eredienste, is dit tog kommerwekkend dat hoorders onverstaanbare prediking as ' $n$ rede aantoon waarom die sinvolheid van erediensbywoning bevraagteken word. Predikers het daarom die baie belangrike taak om moeite te doen met hul prediking, 
sodat die boodskap eenvoudig en verstaanbaar aan hoorders gekommunikeer en as verrykend ervaar sal word.

- Die preekgesprek voor en na die prediking kan predikers help om nie hul preekvoorbereiding in isolasie te verrig nie. Sodoende word die gemeente ook meegeneem in die proses van preekvoorbereiding en preeklewering. Hoorders kry ook deur middel van gesprek met die predikant en medegelowiges die geleentheid om 'n diepgaande gesprek oor die preke te voer. Ook wat kommunikasie tussen prediker en hoorder betref, word voorsiening gemaak vir 'n dinamiese proses van interaksie en terugvoer.

- Hoorders ervaar dat God self onder die diens en veral tydens die prediking aan die woord is.

- Die meerderheid van die respondente $(93,80 \%)$ het duidelik laat blyk dat 'n goeie preek verduidelik wat die teks sê en riglyne gee hoe dit in die praktyk van die lewe toegepas moet word. Dit is dus baie belangrik dat 'n prediker in sy preekvoorbereiding getrou aan die teks met sy hoorders omgaan.

- Prediking speel 'n groot rol in die verandering van verkeerde gesindhede en lewenswyses.

- Hoorders openbaar hoofsaaklik 'n positiewe gesindheid teenoor prediking wat aandui dat hulle hulle laat lei deur wat die Woord openbaar. Dit is daarom noodsaaklik dat die prediking primêr Woordverkondiging sal wees wat erns maak met die verklaring en toepassing van die Heilige Skrif.

- Algemene probleme wat duidelik geword het, is die volgende:

- 'n Onbevredigend klein persentasie van die respondente ervaar die prediker se taalgebruik as duidelik, keurig en eenvoudig.

- Die gebrek aan beeldryke en metaforiese taal om konsepte te konkretiseer veroorsaak dat hoorders steeds worstel met die verstaan van ingewikkelde geloofsfeite.

- Hoorders ervaar probleme as dit kom by die onthou van wat Sondag gepreek is.

- Onverstaanbare prediking word deur sommige hoorders as rede voorgehou waarin die sinvolheid van erediensbywoning bevraagteken word.

- Daar bestaan 'n behoefte aan dialoog tussen prediker en hoorder - 'n behoefte wat duidelik blyk uit die respons. 
Lidmate het 'n behoefte om oor die preke in gesprek te tree met die predikant en ander gelowiges.

- Die prediking inspireer wel die hoorder om iets in sy lewe te verander, maar dit slaag nie so suksesvol daarin om hoorders te inspireer om daadwerklik iets te gaan doen nie.

\section{Slot}

Prediking is 'n Pneumatologiese woordgebeure, waarin die geroepe bedienaar van die Woord, via sy kommunikasie en ervaring met 'n Skrifteks, die gemeente in hul konkrete situasie begelei tot ontmoeting met die lewende God. Om te preek is ook om te skep, om kreatief te wees. Om dit te kan doen, is meer nodig as net ' $n$ kennis van die nodige eksegetiese metodes en 'n aanvoeling van die behoeftes van die gemeente. Die prediker moet op grond van die antieke teks van die Bybel iets nuuts, iets verrassends, moontlik iets ontstellends sê, en wel op só 'n wyse dat die gemeente dit as 'n gepaste en aktuele woord vir hulle en hulle tyd ervaar. Kreatiewe benaderings en vindingryke aanbiedings van die diepe misterie van God se openbaring in Jesus Christus kan deur die Heilige Gees gebruik word om die kerk op te skerp. Die werk van die Gees omsirkel die teks, die gemeente en die prediker asook al die kreatiewe prosesse wat daarin mag afspeel. Dit neem al hierdie dinge in sy diens. Daarom kan die prediker wat kreatief wil preek nie anders as om voortdurend biddend te bly roep: Veni, Creator Spiritus! (Kom, Skepper-Gees!) Kreatiewe prediking is die proses waartydens die prediker (met al sy gawes en talente), onder leiding van die Skepper-Gees, die Woord van God biddend neem en die boodskap daaruit op nuwe/vars maniere aan die gemeente kommunikeer en toepas.

\section{Bibliografie}

CILLIERS, S.P. 1983. Maatskaplike navorsing. Stellenbosch : Kosmos.

DANE, F.C. 1990. Reseach methods. California : Belmont.

DE KLERK, B.J. 1999. Prediking in 'n postmoderne tyd. Die Kerkblad: 24-25, Maart.

DINGEMANS, G.D.J. 1991. Als hoorder onder de hoorders. Hermeneutische Homiletiek. Kampen : Kok.

HEITINK, G. 1999. Practical Theology: history, theory, action domains. Translated by Reinder Bruinsma. Grand Rapids : Eerdmans.

HEYNS, L.M. \& PIETERSE, H.J.C. 1990. Eerste treë in Praktiese Teologie. Pretoria : Gnosis.

KRUGER, F.P. 1999. Prediker en preekgesindheid. 'n Prakties-teologiese studie in die lig van die Pastorale Briewe. Potchefstroom : PU vir $\mathrm{CHO}$. (Th.M.-verhandeling.) 
KRUGER, F.P. 2002. Prediking en gesindheidsverandering. 'n Praktiesteologiese studie in die lig van Hebreërs. Potchefstroom : $\mathrm{PU}$ vir $\mathrm{CHO}$. (Th.D.-proefskrif.)

NAGEL, C.J. Kreatiewe prediking toegespits op die Gereformeerde Kerke in Suid-Afrika - 'n praktyk-teoretiese perspektief. Potchefstroom : PU vir CHO. (Th.M.-verhandeling.)

NEL, M. 2000. Persoonlike prediking. Praktiese Teologie in Suid-Afrika, 15(2):112-135.

PIETERSE, H.J.C. 1979. Skrifverstaan en prediking. Pretoria : NG Kerkboekhandel.

PIETERSE, H.J.C. 1986. Verwoording en prediking. Pretoria : NG Kerkboekhandel.

PIETERSE, H.J.C. 1988. Die Woord in die werklikheid. 'n Teologie van die prediking. Pretoria : NG Kerkboekhandel.

PIETERSE, H.J.C. 1990. A dialogical theory of communication from a practical theological perspective. Evangelical Quartely, 62(3):223-240.

PIETERSE, H.J.C. 1991. Gemeente en prediking. Halfway House : NG Kerkboekhandel.

PIETERSE, H.J.C. 1992. 'n Prakties-teologiese kommunikasieteorie vir die prediking. Praktiese Teologie in Suid-Afrika, 7(1):17-26.

PIETERSE, H.J.C. 2001. Prediking in 'n konteks van armoede. Pretoria : Unisa.

SHÜTZ, W. 1981. Probleme der Predigt. Göttingen : Vandenhoeck \& Ruprecht. (Dienst am Wort 41.)

SMIT, G.J. 1985. Navorsingsmetodes in die Gedragswetenskappe. Pretoria : Opvoedkundige Uitgewers.

VENTER, C.J.H. 1996. Die Woord in die werklikheid. Wetenskapsteoretiese perspektiewe op Diakoniologie. In die Skriflig, 29(1 \& 2):181-202.

VOS, C.J.A. 1996. Die volheid daarvan. Deel I \& II. Homiletiek uit 'n hermeneuties-kommunikatiewe perspektief. Pretoria : Raad vir Geesteswetenskaplike Navorsing.

VOS, C.J.A. 1999. The composition of a sermon. Praktiese Teologie in SuidAfrika, 14(2):120-128.

ZERFASS, R 1992. Grundkurs Predigt 1. Spruchpredigt. Düsseldorf : Patmos Verlag.

\section{Kernbegrippe:}

empiriese navorsing: Gereformeerde Kerke in Suid-Afrika prediking en kreatiwiteit

\section{Key concepts:}

empirical research: Gereformeerde Kerke in Suid-Afrika (Reformed Churches in South Africa; GKSA)

preaching and creativity 